ephemerides of these bodies. Amongst his other lines of research may be mentioned his work on refraction, his tables for the determination of the geographical visibility, measurement of altitudes by the barometer, studies in eertain problems of seismology, and also his zenithal apparatus, described in the Bulletin astronomique, 12, 148, which was capable of making observations simultaneously of the zenith and stars in the vicinity. He was four times awarded prizes by the Paris Academy of Sciences. Astronomical science has lost one whose versatility contributed so much to its progress.

M. D.

\section{Prof. N. V. Nassonov}

Prof. Nicolar Victorovich Nassonov, who has recently died in Leningrad, was the oldest member of the Russian (now U.S.S.R.) Academy of Sciences. He was born at Moscow on February 27, 1855, and in 1874 entered the University of Moscow where he studied under the well-known zoologist, Prof. A. P. Bogdanov, and on obtaining his degree was appointed an assistant and later a lecturer at the Zoological Museum of the University. In 1889, Nassonov joined the University of Warsaw and a year later was appointed to the chair of zoology. In 1909 the Academy of Sciences elected him to membership and he was called to the post of the director of the Academy's Zoological Museum at St. Petersburg. A strenuous period of reorganizing the Museum occupied his time until 1921, when he became director of the Special Zoological Laboratory of the Academy which had been founded by the famous A. O. Kovalevsky. By 1925 this Laboratory, which at first occupied three rooms and had a staff of three men of science, had developed into a large Laboratory of Experimental Zoology and Animal Morphology. It was only in 1935, when eighty years of age, that N. V. Nassonov was persuaded by his medical advisers to retire from active administrative work, but even then he continued researches on regeneration until his death.

The published works of N. V. Nassonov are more than a hundred and seventy in number and deal with a variety of subjects. His earlier morphological work was mainly done on insects and other Arthropoda (ants, Strepsiptera), but later he produced excellent papers on sponges (Clionidx), on the development of the ostrich, on the anatomy and systematics of Turbellaria, a monograph of the wild sheep of the old World, to mention but some of the problems investigated by him with painstaking accuracy and discussed with a broad evolutionary outlook. During the latest period of his work at the Zoological Laboratory, N. V. Nassonov concentrated his attention on regeneration problems, and published a series of outstanding contributions dealing with physiological factors of regeneration, with the morphogenetic function of cartilage, etc.

N. V. Nassonov was well known beyond the borders of his own country, since at various times he visited and worked at the biological stations at Trieste, Marseilles, in the museums in London (1913) and Berlin, and carried out expeditions to Egypt, Sinai and Japan.
N. V. Nassonov's death means the loss of one of the oldest generation of Russian men of science who in the second half of the last century laid the foundation for the development of biological sciences in that country, and whose work served to create for Russian biology an honoured place in the front rank of world science.

B. P. Uvarov.

\section{Prof. H. A. Cummins, C.M.G.}

WE regret to announce the death of Prof. Henry Alfred Cummins, emeritus professor of botany in the University College, Cork. $\mathrm{H}_{\Theta}$ was a member of a family prominent in Cork medical and university life. An elder brother was professor of medicine in the same College.

Cummins was born in 1864. Having taken the M.D. degree in the Royal (now National) University of Ireland, he joined the Royal Army Medical Corps, and was immediately plunged into a series of campaigns. He served in the Sikkim Expedition (1888), Ashanti (1895-96) and in the South African War (1899-1901), during which he was mentioned in dispatches. On the outbreak of the Great War he was recalled for service with the R.A.M.C., and was again mentioned in dispatches. During his military career, he cultivated a keen taste for botany, and managed to collect specimens wherever he might be, even going so far as to shoot epiphytes, otherwise inaccessible, from high forest trees.

In 1909, shortly after his retirement as Major, Cummins was appointed professor of botany in University College, Cork, a constituent college of the National University of Ireland. He held this position until 1931.

Cummins had a personality of considerable charm. $\mathrm{He}$ followed his original interests in spermaphytes with histology and cytology. Just before his retirement, he carried out experiments on the reclamation of estuarine shores near Cork by means of the rice grass, Spartina Townsendii. These appear to have been the first attempts at such reclamation in Ireland.

J. C. Sperrin-Johnson.

WE regret to announce the following deaths :

Prof. F. J. Cheshire, C.B.E., formerly director of the Optical Engineering Department, Imperial College of Science, London, on March 24, aged seventy-eight years.

Prof. Vasili Y. Danilevsky, of Kharkov, known for his work in physiology and endocrinology, on February 25, aged eighty-seven years.

Mr. L. J. Newman, Government entomologist of Western Australia, on December 8, aged sixty years.

Baron Joji Sakurai, honorary professor of chemistry in the Imperial University of Tokyo, president of the Imperial Academy and the National Research Council of Japan, on January 28, aged eighty years.

Prof. John H. Schaffner, professor of botany in the Ohio State University, an authority on the taxonomy and phylogeny of the Ohio and Kansas flora, on January 27, aged fifty-five years. 